$\mathrm{EFCC}$

2,3

Received 22 November 2020 Revised 1 June 2021 Accepted 11 June 2021

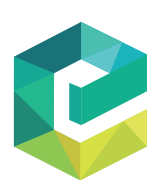

Ecofeminism and Climate Change Vol. 2 No. 3, 2021 pp. $110-126$

Emerald Publishing Limited

e-ISSN: $2633-4070$

p-ISSN: $2633-4062$

DOI 10.1108/EFCC-11-2020-0033

\section{Identifying the causes of waterlogging on people's perception towards a resilient community: a case study on Pabna Municipality, Bangladesh}

\author{
Mazed Parvez \\ Department of Urban and Regional Planning, \\ Bangladesh University of Engineering and Technology, Dhaka, Bangladesh \\ Nazmus Sadat and Farhana Tasnim \\ Department of Urban and Regional Planning, \\ Pabna University of Science and Technology, Pabna, Bangladesh, and \\ Israt Jahan Nejhum \\ Department of Urban and Regional Planning, \\ Bangladesh University of Engineering and Technology, Dhaka, Bangladesh
}

\begin{abstract}
Purpose - Pabna is suffering from waterlogging problems from ancient times. The previous Drainage Master Plan was failed due to the lack of reflection of the general people of Pabna Municipality. As a result, this study focuses on identifying the causes of waterlogging in people's eyes. This paper will help the local authority and planners eradicate the waterlogging problem and build a planned and resilient community.

Design/methodology/approach - Both primary and secondary data were used for the study. Present drainage pattern, topology climatic elements were collected from the journals, websites and Municipal Ingratiated Development Plan (MIDP), Pabna-2008. The sample size was 246, and this respondent was surveyed. By the survey, the people's perception of waterlogging was collected. For that, five independent variables and one dependent variable were determined. These variables were determined by previous studies, reconnaissance survey of the study area. It used multiple linear regression and the correlation method; the causes of waterlogging were determined.

Findings - The study found solid waste disposal into the drainage, absence of operation and maintenance system, small discharge capacity with blocked in the current drains, nonappearance of combined drainage network of roadside drains and unplanned drainage system as the leading causes of waterlogging from the perception of the people. Also found that the absence of operation and maintenance system, solid waste disposal into the drainage and unplanned drainage system as the influencing causes on small discharge capacity with blocked in the current drains.
\end{abstract}

Originality/value - This study has focused on people's perceptions rather than secondary data. That is why this study will significantly impact eradicating the waterlogging problem from the Pabna Municipality and will carry out the core problems without any bias. This will lead to a sustainable, planned and resilient community. Keywords Urban planning, Consumer perception, Disaster management, Community perception, Waterlogging

Paper type Case study

(C) Mazed Parvez, Nazmus Sadat, Farhana Tasnim and Israt Jahan Nejhum. Published in Ecofeminism and Climate Change. Published by Emerald Publishing Limited. This article is published under the Creative Commons Attribution (CC BY 4.0) licence. Anyone may reproduce, distribute, translate and create derivative works of this article (for both commercial and non-commercial purposes), subject to full attribution to the original publication and authors. The full terms of this licence may be seen at http:// creativecommons.org/licences/by/4.0/legalcode 


\section{Introduction}

Bangladesh is situated on the broad floodplains of the Ganges and Brahmaputra stream frameworks. Consequently, flooding is a distinctive aspect of its occupants (Mowla and Islam, 2013). Flooding causes wide-ranging devastation, economic compensations and loss of human lives (Knight, 2011; Bansal et al., 2015). From the earliest starting, urban regions are at a better threat to flooding because of the accelerated rainfall-runoff extent and greater exposure of people and assets because of resources' awareness (Sato, 2006). Considerable increment in developed regions has occurred because of territories' inhumane advancements through private land designers and land business (Tawhid, 2004).

Urban waterlogging happens much of the time and regularly causes impressive harm that genuinely influences the typical habitat, human life and the social economy. The spatial assessment of metropolitan waterlogging hazard speaks to a fundamental diagnostic advance that can be utilized to forestall urban waterlogging and minimize related misfortunes (Tang et al., 2018). Foremost climate alteration phenomena (i.e. extreme rainfall and the late discharge instigated by sea-level rise) are primarily answerable for continuous waterlogging in Bangladesh's metropolitan regions (Alam and Rabbani, 2007; Cazenave et al., 2014).

The waterlogging of Pabna city is one of the problematic matters for the Pabna district authority. In the wet season, it creates plenty of issues for the occupants of this region. It hampers their monetary exercises and just as in everyday life (Hasan et al., 2018). A master plan for Pabna Municipality under the Upazila Town Master Plan for the first time in 1987 with Ahmed Associates and Consultants Ltd's provision by the Urban Development Directorate (UDD) was made. "Drainage, sewerage, water and electricity" was planned in field the MIDP plan recommended to work out a superior drainage plan for the metropolitan using the Ichamoti river on that plan in the MIDP. The Pabna Pourashava Drainage Master Plan was prepared under the Secondary Town Infrastructure Development Project (STIDP) in 1993. The Asian Development Bank (ADB) funded the project, and the Local Government Engineering Department (LGED) was the principal custodian (MIDP, 2008). After checking on the Drainage Master Plan-1993, it is discovered that the municipality has actualized just $70 \%$ depletes according to the Drainage Master Plan. The absence of monetary assets was the prime reason for the nonexecution of waste groundbreaking strategy recommendations (Hasan et al., 2018).

Drainage conditions are not acceptable in the Pabna Paurashava area. There are small numbers of Reinforced Cement Concrete (RCC) drains. There are large numbers of brick drains that are old, and their condition is not good. Faulty design, solid waste, rubbish dumping, encroachment and unauthorized structures, siltation, lack of renovation and reexcavation are the leading causes of drainage congestion. In this circumstance, a fruitful plan for waterlogging must solve the problem in the Pabna Municipality. Though $70 \%$ of the drainage master plan's work was completed, the waterlogging problem still exists. The perception of the community was missing from those plans. As a result, the methods do not work correctly and cannot solve the waterlogging. This study aims at finding out the causes of waterlogging on the perception of the stakeholders and shall provide some recommendations to solve the problem on the stakeholder's perceptions.

A participatory-based vulnerability investigation incorporates the influenced individuals in characterizing issues and needs, concluding answers for them, executing concurred exercises to accomplish those arrangements and assessing the outcomes. The advantages of the method are the development of limit and the debacle production hazards the board perspectives, conduct and a more substantial knowledge into the networks empowering better outcomes. The participatory investigation might be more financially savvy in the long haul than remotely determined activities, halfway because they are bound to be feasible and because the cycle permits thoughts to be tried and refined before selection.
The causes of waterlogging 
EFCC

2,3

112

Waterlogging implies the stale of water, which is brought about by usually and artificial. It has a stable relationship with salary or financial return for the land. At present, waterlogging is one of the consuming issues of Bangladesh. The wetland territories that function as a standard asset are declining because of populace pressure. It expands the likelihood of waterlogging. Pabna is a secondary township in Bangladesh. There are 15 wards at the Pabna Municipality. In total, 246 (Sample size, $n=246$ ) stakeholders were surveyed among the 15 wards. Almost all the words are facing waterlogging problems. The town master plan and the drainage plan intensify the most vulnerable areas and provide a working procedure for solving the problem.

Nevertheless, the perception of stakeholders of the municipality was deprived of the plan. As a result, the waterlogging problem is still existing in the area. This study will focus on finding out the existing waterlogging and drainage system of the municipality. Moreover, it will also carry out people's perception of waterlogging and determine the most vulnerable areas and the leading causes of waterlogging problems. Finally, the study will provide recommendations with stakeholder participation to help the authority make a fruitful sustainable plan for the upcoming days.

\section{Literature review}

The waterlogging issue has become a severe issue in a considerable number of metropolitan cities. So, the unique adherence to the waterlogging circumstance in the urban refers to on the world (Anisha and Hossain, 2014). These days, waterlogging is a major issue everywhere in the world remembering Bangladesh for the 21 st century. It may be considered a terrible outcome of innovative utilization and monetary advancement in present situation (Majumder et al., 2018). The wetland territories that function as a standard asset are declining because of populace pressure. It expands the likelihood of waterlogging (Tang et al., 2018). Metropolitan regions are at a greater danger of flooding due to expanded precipitation spillover volume and individuals' unique presentation (Blanc et al., 2012).

There are numerous parts of weakness, emerging from different physical, social, financial and natural elements. Waterlogging is the circumstance of flooding in buildup zones brought about by precipitation, where water stays stale for a long time because of the absence of appropriate waste framework and makes numerous unfriendly effects on the day by day life (Atauzzaman et al., 2019). One of the primary methods for tackling this problem lies in explaining the jobs played by the spatial components of urban surfaces that cause metropolitan waterlogging, just as in foreseeing metropolitan waterlogging hazards (Tran et al., 2020). Regarding environmental change, waterlogging because of rainstorms is getting more regular and genuine in nonindustrial nations. It is making misfortunes to the economy, just as influencing the living climate, individuals' day-by-day lives and the practical advancement techniques of urban communities (Tang et al., 2018). Urban roads go about as streams by gathering water, consequently expanding the volume of surface spillover, one of the most widely recognized reasons for metropolitan waterlogging (Tam and Nga, 2018; Sajikumar and Remya, 2015).

These exercises brought about generous increment in the impenetrable region, made the block to regular seepage design and diminished detainment bowls, leading to shortening of the spillover focus time and expanding the pinnacle stream. Accordingly, flooding because of precipitation is a severe issue for any city that remaining parts immersed after each extreme shower fundamentally because of the waste clog (Huq and Alam, 2003). Disruption of traffic movement and normal life, damage of structures and infrastructure, destruction of vegetation and aquatic habitats, loss of income potentials are the prime effects of waterlogging (Cazenave et al., 2014). The rainfall-induced flooding that is caused by high-intensity rainfall runoff in the city area is mainly due to the lack of a proper drainage system and inefficient 
management (Mowla and Islam, 2013). Vulnerability is a degree to which individuals, property, asset frameworks and social, financial, natural and social action are defenseless to damage, corruption or obliteration on being presented to a threatening specialist. There are numerous parts of weakness, emerging from different physical, social, financial and natural variables (Islam et al., 2015). The reasons for waterlogging will assume a significant function for distinguishing the arrangement of this difficult circumstance alongside improving the financial states of the people groups of that waterlogged territory (Hasan et al., 2018).
The causes of waterlogging

\section{Materials and methods}

\subsection{Study area profile}

3.1.1 Overview of the study area. It is the Pabna region which is probably the most seasoned region in Bangladesh, and it was set up in 1876 (Figure 1). In 1868, Pabna Town Committee was set up before the Pabna Municipality foundation. Pabna district was moved up to the "A" category region in 1989. It is arranged at $161 \mathrm{~km}$ Northwest of Dhaka city and $110 \mathrm{~km}$ East of Rajshahi city. The zone of the district is around $16 \mathrm{~km}^{2}$ with a populace of 133,403 . The zone is dispersed between $23^{\circ} 53^{\prime \prime} \mathrm{N}$ and $24^{\circ} 05^{\prime \prime} \mathrm{N}$ scope and $89^{\circ} 09^{\prime \prime} \mathrm{E}$ and $89^{\circ} 25^{\prime \prime} \mathrm{E}$ longitudes. There are 15 wards comprise of the Pabna Municipality (Parvez and Islam, 2020).

It is bounded by Shalgaria and Laskorpur beyond the river Ichamoti on the north, Dakshin Ramchandrapur on the south, Arifpur-Mahendrapur-Madarbaria on the east and Hemayetpur and Pailanpur on the west part of the Paurashava. Pabna Paurashava is a land of mixed topography. The Ichamoti river is passing through the middle of the Pourashava along the north-south direction. But presently this river is in dead condition. The Ichamoti river is filled with water weeds and siltation. The river lost her navigation during the long years (Hasan et al., 2018).

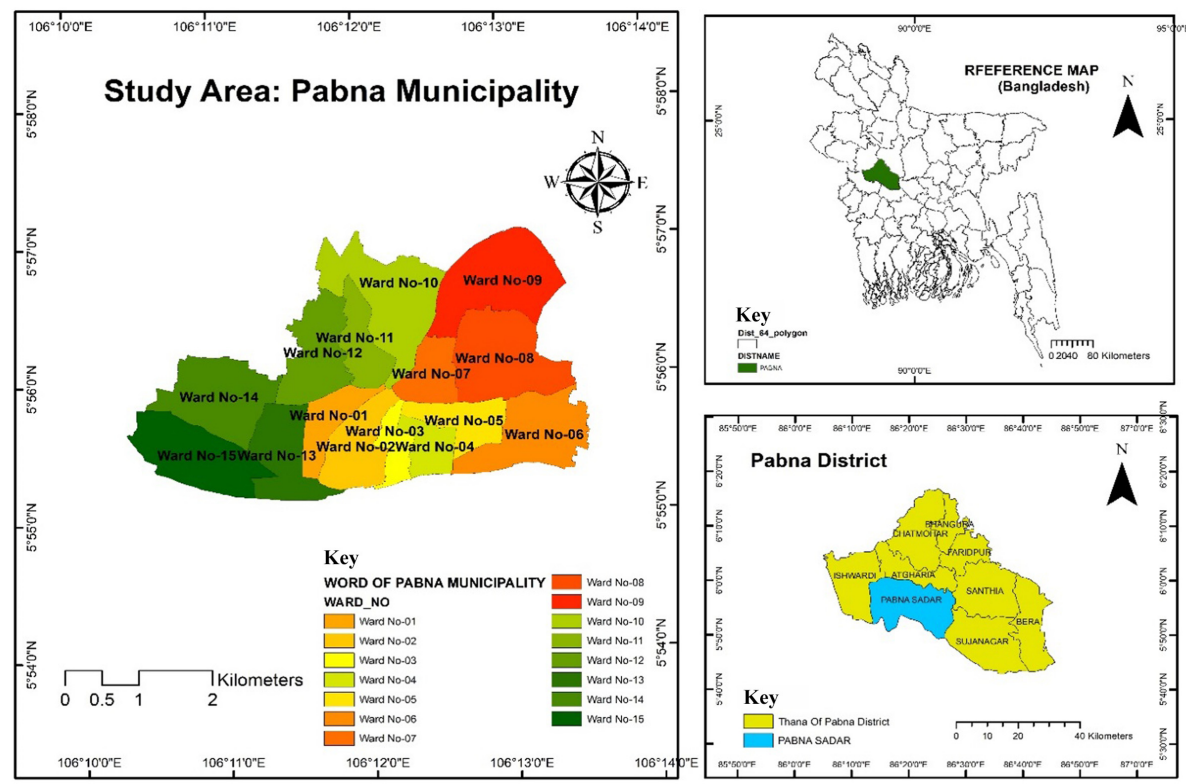

Source(s): Authors, 2020

Figure 1. Study area profile 
EFCC

2,3

114

The absolute land reserved for business use remains at $2.51 \%$ of the all-out metropolitan region alongside mechanical land secured just $4.44 \%$, complete land reserved for instructive class remains at $4.45 \%$, the all-out land under transportation use has been discovered $6.85 \%$ and office utilize $2.11 \%$ (ADB, 2014).

Inundation occurs due to localized storm rainfall and also due to other causes affecting the drainage system within Pabna Paurashava. External flood is not likely to occur in the Paurashava area. Ichamoti river has been blocked due to the Bangladesh Water Development Board (BWBD) cross-dam near Ataikula. The downstream part of the river is silted up by encroachment during the long ages. During the peak monsoon period only, internal flow occurs in some specific areas within the Paurashava area and affects the waterlogging (MIDP, 2008).

3.1.2 Topography. Pabna Paurashava is a land of mixed topography. The Ichamoti river is passing through the middle of the Paurashava along the north-south direction. But presently this river is dead. The Ichamoti river is filled with water weeds and siltation. The river lost her navigation during the long years. The elevation of the Paurashava area varies from $11 \mathrm{~m}$ to $14 \mathrm{~m}$ PWD. There are four bench marks embedded in the different points in the Paurashava as per the Survey of Bangladesh (SOB) bench mark in the Pabna Polytechnic Institute. The Ichamoti river divides the Pabna Paurashava into two parts and joins the dead Padma river to the south. The ground level along the river banks and the core area along the middle of Paurashava are higher than the other part of the Paurashava. There is no danger of river water intrusion into the Paurashava area because of the dead condition of the Ichamoti river. But some areas of the Paurashava are subjected to inundation during and after heavy rainfall (MIDP, 2008) (see Figure 2).

3.1.3 Climate. Pabna enjoys a tropical monsoon type of climate where the mean annual rainfall is $1,521 \mathrm{~mm}$ and the annual mean temperature is about $25.08^{\circ} \mathrm{C}$. The climate of Pabna Paurashava is moderate. The mean monthly maximum temperature is observed during the month of May and June where it attains $29.0^{\circ} \mathrm{C}$, and the monthly minimum temperature occurs in January when it is about $16.04^{\circ} \mathrm{C}$. Summer begins in April and continues till August. The mean monthly temperature and rainfall of Pabna Paurashava are shown in Table 1. Monsoon normally starts from April and continues up to October. The annual mean rainfall is $1,521 \mathrm{~mm}$ of which the maximum mean monthly rainfall is about $314 \mathrm{~mm}$, which occurs in September (MIDP, 2008).

\subsection{Land use}

There are 16 classes for existing land uses and proposed land uses under the Municipal Infrastructure Development Plan. The largest mauza is Shalgaria, which is covered by $722.069(18.70 \%)$ acres of land. The second-largest mauza is Chatiani, which covered by $435.778(11.28 \%)$ acres of land. The third-largest mauza is Rdhanagar, but it not covered completely. The Radhanagar mauza is partially covered by $402.286(10.42 \%)$ acres of land. The above three mauza covered $40 \%$ of the land of the total Paura area. The very smallest mauza is Shinga, which not only covered the Paura area but also covered the outside the Paura area. The linear strip of Shing mauza along the Ichamoti river covered only 17.63 acres of land. The total water body area of the water bodies of the municipality covers $7.93 \%$ of the total area, and the total area of the water body is 306.281 acres. Gopalpur mauza is the most dominated land use as per government offices and educational institutions. Pabna Jailkhana is also situated in Gopalpur mauza. It can be said that the Gopalpur mauza is the oldest area of Pabna Paurashava (MIID, 2008).

\subsection{Methods}

To fulfill the objective of the study, the whole study has been conducted following an orderly step-by-step process. Both primary and secondary data were used for conducting the study. 

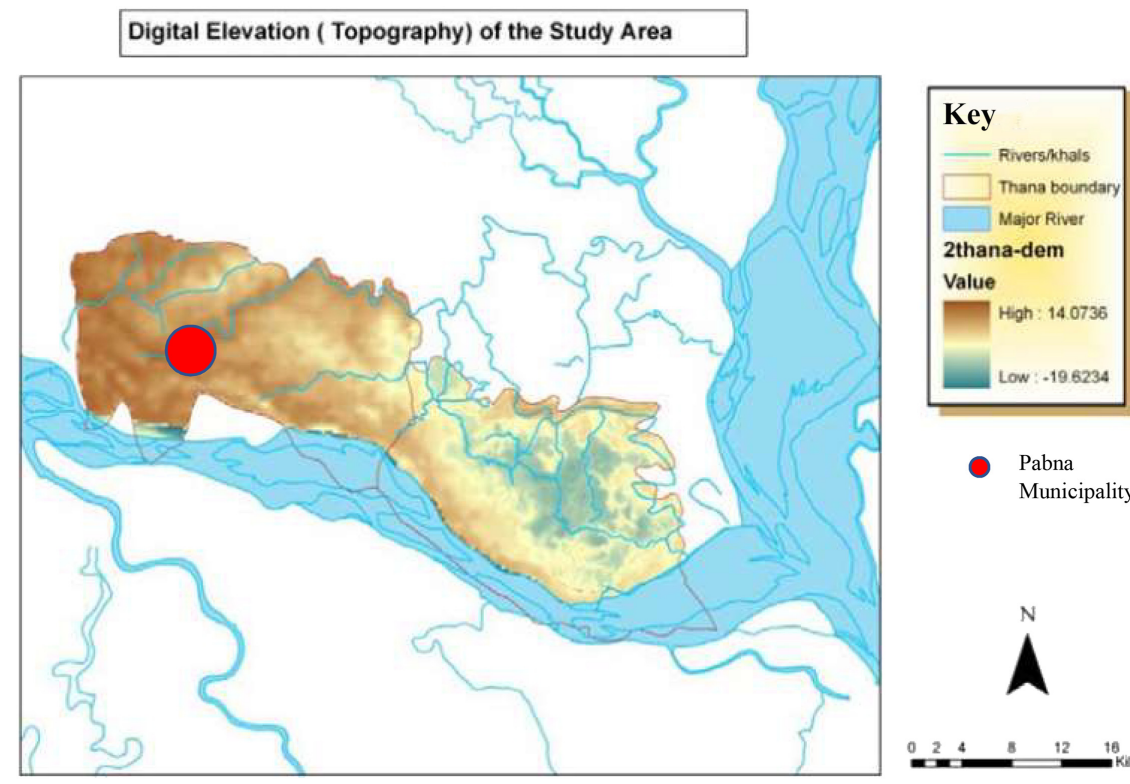

The causes of waterlogging

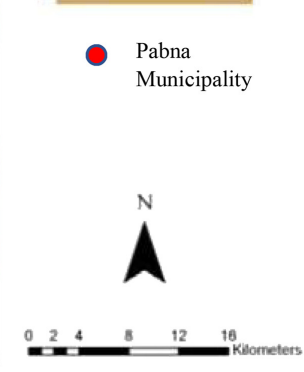

Source(s): Sultana, 2012

Figure 2.

Topology of study area

\begin{tabular}{lcclcc}
\hline Month & Rainfall $(\mathrm{mm})$ & Temperature $\left(0^{\circ} \mathrm{C}\right)$ & Month & Rainfall $(\mathrm{mm})$ & Temperature $\left(0^{\circ} \mathrm{C}\right)$ \\
\hline January & 5 & 16.4 & July & 292 & 28.5 \\
February & 22 & 20.0 & August & 224 & 28.7 \\
March & 35 & 24.9 & September & 314 & 28.2 \\
April & 70 & 28.6 & October & 129 & 26.6 \\
May & 165 & 29 & November & 18 & 22.7 \\
June & 241 & 29 & December & 6 & 18.3 \\
& & & & 1,521 & $25.08^{\circ} \mathrm{C}$
\end{tabular}

Source(s): Atauzzaman et al. (2019)

Table 1.

Mean monthly rainfall and temperature of Pabna Paurashava

Both national and international journals, books and papers regarding satisfaction assessment of public transport were studied. For determining the sample size, the following equation is used:

$$
n=\frac{z^{2} \rho q N}{(N-1) \mathrm{e}^{2}+z^{2} \rho q}
$$

where $n$ is the sample size, $Z$ is the value of the standard normal deviate at $95 \%$ confidence level (1.96), $p$ is the sample proportion, $q$ is equal to $(1-p), e$ is the acceptable margin of error (0.05) and $N$ is the number of population (Kobra et al., 2018). Here the total number of populations of Pabna Municipality is 168,125 , so $N=168,125$. The sample proportion $p$ is 0.20 . So, from the equation, the sample size is determined $n=246$. In total, five variables (solid waste disposal into the drainage, absence of operation and maintenance system, small discharge capacity with blocked in the current drains, nonappearance of combined drainage 
EFCC

2,3

116

network of roadside drains and unplanned drainage system) were determined from the help of a reconnaissance survey and previous studies, e.g. MIDP, journals or reports. A five-point Likert scale ranged from "1" = Severe problematic, "2" = problematic, "3" = Moderate, "4" = Not problematic and " $5 "=$ Not severe problematic was used to find out the respondent's satisfaction scenario. The overall perception for the respondent was calculated based on a mean score of all five variables value. For collecting the satisfaction level of the passenger's data, a questionnaire survey was conducted in 15 wards of Pabna Municipality. The questionnaire was asked on the five variables along with the socio-economic information, age, occupation, gender and employment. The data collected from the questionnaire survey was recorded in SPSS. The data were analyzed by correlation and regression methods. The relationship between the dependent variable and independent variables is explicated through the following equation.

$$
Y_{i}=\alpha+\beta_{1} X_{i}+\beta_{2} X_{i}+\beta_{3} X_{i}+\ldots \ldots+e_{i}
$$

where $Y$ is the dependent variable, $\alpha$ is the constant, $\beta_{i}(i=0,1,2,3 \ldots \ldots, n)$ is the regression coefficients, $X_{i}(i=0,1,2,3 \ldots \ldots, n)$ is the independent variables and $n$ is the number of the independent variable. $e_{i}$ is independent and identically distributed with a Gaussian distribution with mean 0 (Tran et al., 2020). These methods help to predict the perception level of the consumer on waterlogging. Some relevant proposal has also been suggested based on the outcome of the questionnaire survey.

Causes of water logging $=f$ (Performance factors, improve living standard of poor factors, fame rising factors)

$\operatorname{LnPP} P_{i t}=\beta_{0}+\beta_{1} \operatorname{LnSD}_{i t}+\beta_{2} \operatorname{Ln} \mathrm{AOS}_{i t}+\beta_{3} \operatorname{LnSDC}_{i t}+\beta_{4} \operatorname{LnNCD}_{i t}+\beta_{4} \operatorname{LnUD}_{i t}+\mu_{i t}+\varepsilon_{i t}$

where PP means the problematic perception level of consumers, and it is the dependent variable. The $\mathrm{SD}_{i t}$ represents the solid waste disposal variable. $\mathrm{AOS}_{i t}$ represents the Absence of operation and maintenance variable; $\mathrm{SDC}_{i t}$ represents the small discharge capacity variable. The $\mathrm{NCD}_{i t}$ represents the nonappearance of combined drainage network variable. And finally, $\mathrm{UD}_{i t}$ represents the unplanned drainage system variable (see Table 2).

By utilizing the Pearson connection investigation, the creators recognize the relationship among the factors. Pearson connection is a notable equation to decide the connections among factors appropriately. In addition, from past investigations, the creators discover the Pearson connection is a satisfactory recipe. The creators utilized the accompanying condition of Pearson correlation to decide the connections among the factors.

$$
\mathrm{r}=\frac{n \sum x y-\sum x \cdot \sum y}{\left[\sqrt{[n} \sum x^{2}\left(\sum x\right)^{2}\right] \cdot\left[\sqrt{[n} \sum y^{2}\left(\sum y\right)^{2}\right]}
$$

where $r=$ Pearson's correlation coefficient, $\sum x y=$ Number of pairs of values or scores, $n \sum x y=$ Sum of the outcome of $x$ and $y, \sum x=$ Sum of the $x$ values $\sum y=$ Sum of the $y$ values (or $y$ scores), $\sum x^{2}=$ Sum of squares of $x$ values, $\sum y^{2}=$ Sum of squares of $y$ values, ) = Square of the Sum of $x$ values and $\left(n \sum y\right)^{2}=$ Square of the sum of $y$ values (Sajikumar and Remya, 2015).

\section{Exploratory analysis}

\subsection{Existing drainage pattern}

Physical surveys were carried out in both the core and fringe areas of Pabna Paurashava to identify and prepare a physical inventory of existing physical infrastructure facilities in terms of drainage, culverts and bridges. The consultants identified the necessarily proposed 


\begin{tabular}{ll}
\hline Classification & Variables \\
\hline Dependent & Problematic perception level of consumers (PPs) \\
Independent & Solid waste disposal into the drainage (SD) \\
& $\begin{array}{l}\text { Absence of operation and maintenance system } \\
\text { (AOS) }\end{array}$ \\
& $\begin{array}{l}\text { Small discharge capacity with blocked in the } \\
\text { current drains (SDCs) } \\
\text { Nonappearance of combined drainage network of } \\
\text { road side drains (NCDs) } \\
\text { Unplanned drainage system (UD) }\end{array}$
\end{tabular}

Source(s): Authors analysis 2020
Description

People faces the problem on waterlogging

Deposal makes block on the free flow movement of water

Cause blockage on water movement

Cause overflow of water at the drains

Water stand still and cause

waterlogging

Water can not move freely through the drain

Table 2.

Variables of the model

drains, which have to be undertaken for the 2 nd phase. As per survey results, the consultants found the existing Ichamoti river $7.9 \mathrm{~km}$ (Table 3), primary drain $11.29 \mathrm{~km}$, secondary drains $56.23 \mathrm{~km}$, existing tertiary drains $28.16 \mathrm{~km}$ and existing borrow pit $3.25 \mathrm{~km}$. Waterlogging areas and inundation areas are also identified, including the duration and depth of inundation.

The Ichamoti river serves as the main drainage channel of the surface runoff for the Paurashava area. At some of the places, the waterways, namely secondary and tertiary drains, are obstructed by solid wastes, encroachments, etc. resulting in decreasing the drainage system's discharge capacity and eventually creating inundation of water. Inundation of water in some places is causing an environmental hazard (Sultana, 2012). It may be mentioned here that the Pabna Paurashava area has no proper drainage system. In the core areas, drains lie along the bank of the river Ichamoti. As the Ichamoti river is a dead channel, there is no possibility of backflow from the river Ichamoti. Some borrow pits namely bypass borrow pit, Radhanagar borrow pit along the PI road and police line-technical borrow pit. Arifpur khal which outfall into Padmar kul river (MIDP, 2008). Inundation occurs due to localized storm rainfall and other causes affecting the drainage system within Pabna Paurashava. External flood is not likely to occur in the Paurashava area. Ichamoti river has been blocked due to the BWDB cross-dam near Ataikula. The downstream part of the river is silted up by encroachment during the long ages. During the peak monsoon period only, internal flow occurs in some specific areas within the Paurashava area and affects waterlogging. Erosion does not occur in the Paurashava area. The Ichamoti river had already been lost her natural levy many years ago. Other rivers like Padma Kul, Shib Ganga river and

\begin{tabular}{llr}
\hline Sl no & Drain type & Length in km \\
\hline 01 & River & 7.9 \\
02 & Borrow pit & 3.25 \\
03 & Primary & 11.29 \\
04 & Secondary & 56.23 \\
05 & Tertiary & 28.16 \\
& & 106.83
\end{tabular}

Source(s): Drainage Inventory Survey, 2007

Table 3. Types of drains and their length 
EFCC

2,3

118
Arifpur river are dammed differently. So, erosion is absent in the Pabna Paurashava area (Sultana, 2012) (see Table 4).

The existing populace in 2019 changed into estimated as 11,222. Table 1 indicates the estimated sewage flows that could doubtlessly attain the sewer network. Considering the accumulation of sludge inside sewers, sewers' capacity was assumed to be equal to $70 \%$ of the overall drift potential. The ability of the present sewer is $0.29 \mathrm{~m}^{3} / \mathrm{s}$ with a drift velocity of zero. The prevailing sewer machine could accommodate the prevailing and improved sewage and go with the flow inside the destiny up to 2050. It was visible throughout the subject visit that the sewage flow is below a minimum speed of zero, $6 \mathrm{~m} / \mathrm{s}$ at a few locations and stagnant at some places due to sedimentation of sludge, accumulation of solid waste, flowers in drains, discontinuity of drains and so forth (Atauzzaman et al., 2019) (see Figure 3).

\subsection{Existing waterlogging scenario}

The flawed drainage system is the acute problem that has been identified by ward commissioners and Paurashava residents. It may be mentioned here that many drains in the urbanized areas within the Paurashava are found to be inadequate. Localized flooding occurs during and after heavy rainfalls causing inconvenience to the residents and spreading waterborne diseases (MIDP, 2008) (see Plate 1).

Nevertheless, from the field study, the following areas are identified as waterlogging affected zones:

(1) South Raghabpur area

(2) Uttar Shalgaria

(3) Islamic Degree college area

(4) Homiopathy Medical College area

(5) Arifpur

(6) Noynamoti

(7) Pailanpur

(8) Radhanagar

(9) Jorebangla area

(10) Mental hospital

(11) Kismotprotappur

\begin{tabular}{|c|c|c|c|c|c|}
\hline $\begin{array}{l}\text { Ward } \\
\text { no }\end{array}$ & $\begin{array}{c}\text { Area } \\
\text { (sq.km) }\end{array}$ & $\begin{array}{c}\text { Storm flow } \\
\left(\mathrm{m}^{3} / \mathrm{s}\right)\end{array}$ & $\begin{array}{l}\mathrm{M} \\
\text { pro } \\
\text { storm } \\
(\%)\end{array}$ & $\begin{array}{l}\text { lost } \\
\text { bable } \\
\text { a flows } \\
\left(\mathrm{m}^{3} / \mathrm{s}\right)\end{array}$ & Remarks \\
\hline 4 & 1.61 & 34.08 & 50 & 17.04 & \multirow{4}{*}{$\begin{array}{l}\text { The most probable storm flows from surrounding areas } \\
\text { were determined based on questionnaires and field } \\
\text { visits }\end{array}$} \\
\hline 5 & 1.61 & 34.08 & 100 & 34.08 & \\
\hline 6 & 2.41 & 51.01 & 60 & 30.61 & \\
\hline 8 & 2.41 & 51.01 & 40 & 20.40 & \\
\hline \multicolumn{6}{|c|}{ Source(s): Atauzzaman et al. (2019) } \\
\hline
\end{tabular}

Table 4.

Estimated sewage flows that could potentially reach the sewer network 


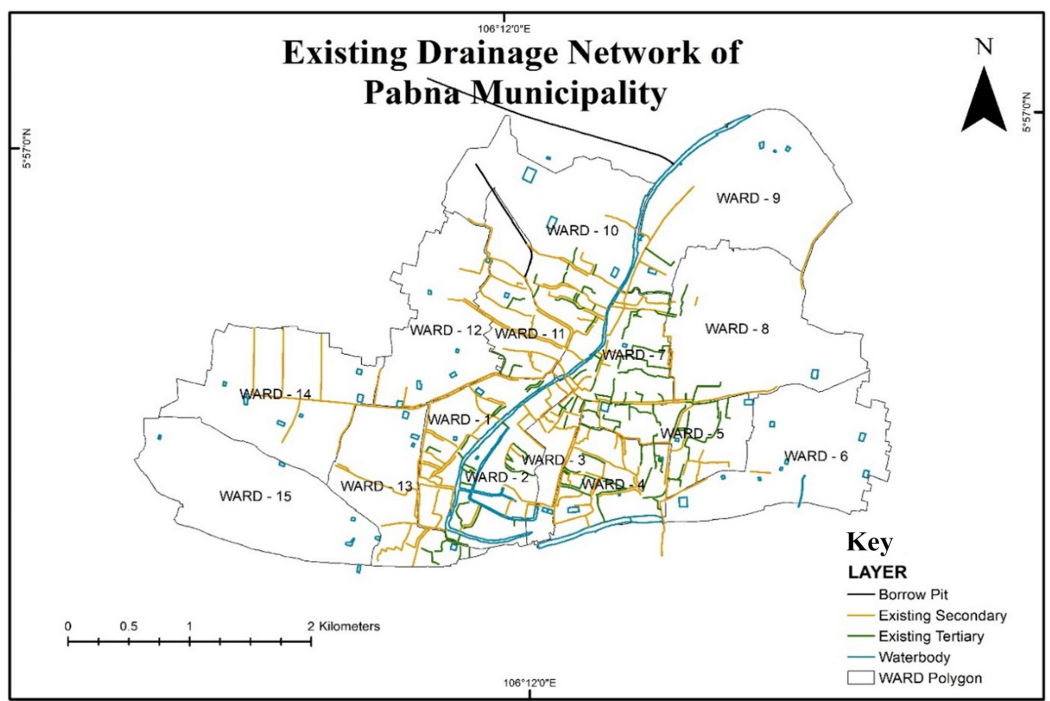

Source(s): Authors, 2020
The causes of waterlogging

119
Figure 3. Existing drainage network

From the field survey, it is seen that all 15 wards are affected by waterlogging problems. From the field survey, it is found that almost $86 \%$ are infected by waterlogging every year. Annually, the infected rate is $8.6 \%$. At every five-year, $5.6 \%$ are infected by waterlogging, and the total infected household percentage is $56 \%$ of the municipality (see Figure 4).

Almost $44.6 \%$ of households are affected by waterlogging every year for one day. On average, $11 \%$ of households are affected by waterlogging for 1-3 days. In total, $38 \%$ of households do not affect by any waterlogging. Nevertheless, 4 and $0.9 \%$ population are affected by waterlogging on an average of $3-15$ days and $15-30$ days. Only $1.5 \%$ of people are infected by waterlogging for more than 30 days.

\subsection{Consumer perception determination}

A total of five variables (solid waste disposal into the drainage, absence of operation and maintenance system, small discharge capacity with blocked in the current drains, nonappearance of combined drainage network of roadside drains and unplanned drainage system) were determined to find out the consumer perception on waterlogging in Pabna Municipality. Figure 5 visualizes the word-wise consumer perception of the present waterlogging situation. A five-point Likert scale was established to find out the present waterlogging situation. All the consumers of all the 15 words identify waterlogging as a problematic scenario. On average, over $70 \%$ or more consumers of Ward no - 1,4,7,15, 60\% or above consumers of Ward no - $(3,6,8,10,14)$ and $50 \%$ or more consumers of Ward no - 5,11,12,13 identify waterlogging as a severe problematic scenario. On average, over $25 \%$ or more consumers of Ward no $-5,11$ and $15 \%$ or above consumers of Ward no - 3,4,6,8,10,12,13,14 identify waterlogging as a problematic scenario. The rest of the consumers have the on waterlogging as a problematic scenario of less than $15 \%$. On average, over $10 \%$ and above consumers of Ward no -1,6,7,11,12 and $6 \%$ or above consumers of Ward no - 3,5,8,10,13,14,15 identify waterlogging as identify waterlogging as a moderate problematic scenario. The rest of the consumers have the on waterlogging as a problematic scenario of less than $6 \%$. Very few consumers identify waterlogging as not a problem or not a severe problematic scenario (see Figure 6). 


\section{EFCC 2,3}

120

Plate 1.

Visual of existing waterlogging problem
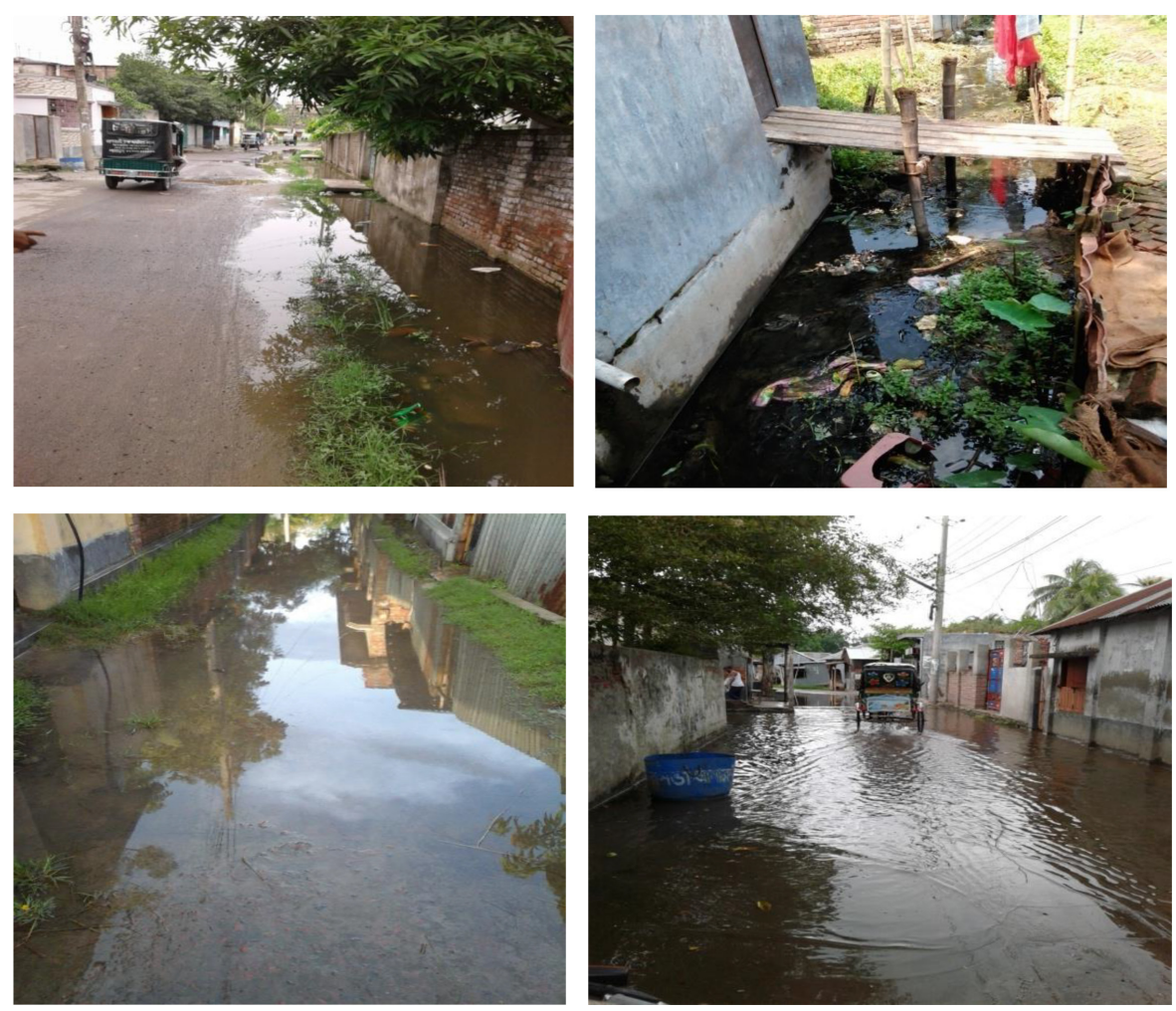

Source(s): Field Survey, 2020
Figure 4.

Pabna city average

frequency of waterlogging (in percentage)
Water logging frequncy

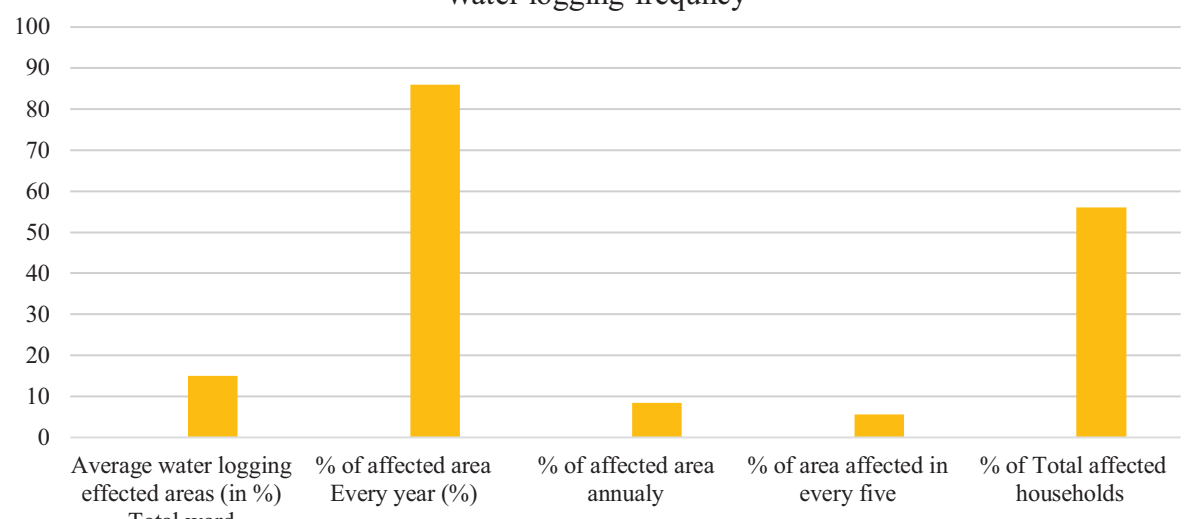

Source(s): Field Survey, 2020 
Annually Affected households with average in \% duration of water

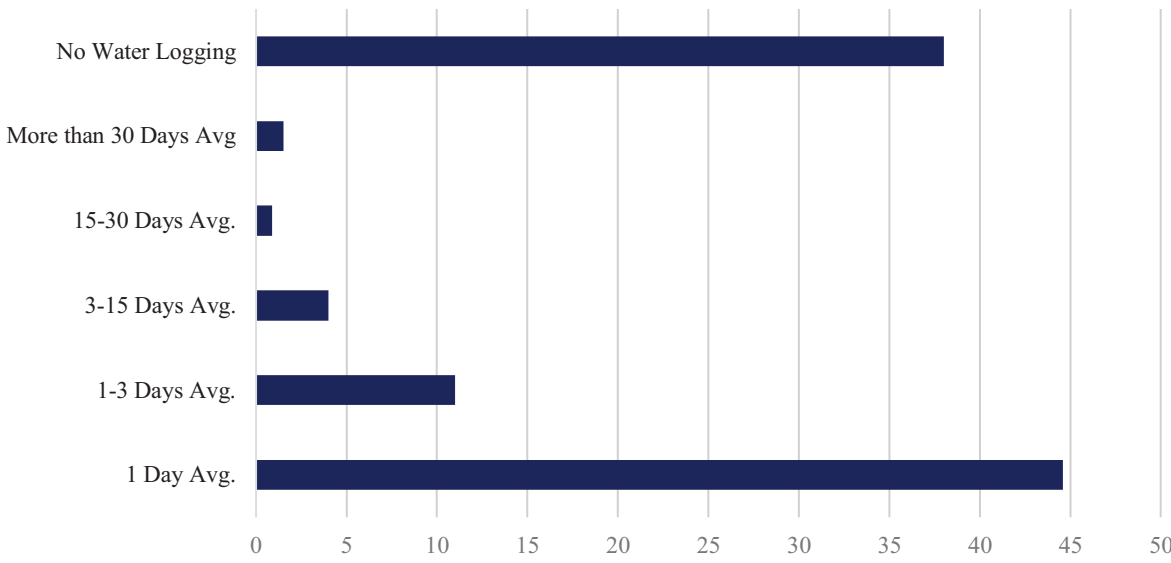

Source(s): Field Survey, 2020
The causes of waterlogging

Figure 5.

Annually waterlogging affected households in leu of a duration of water (average)
Word-wise Perception Level of People

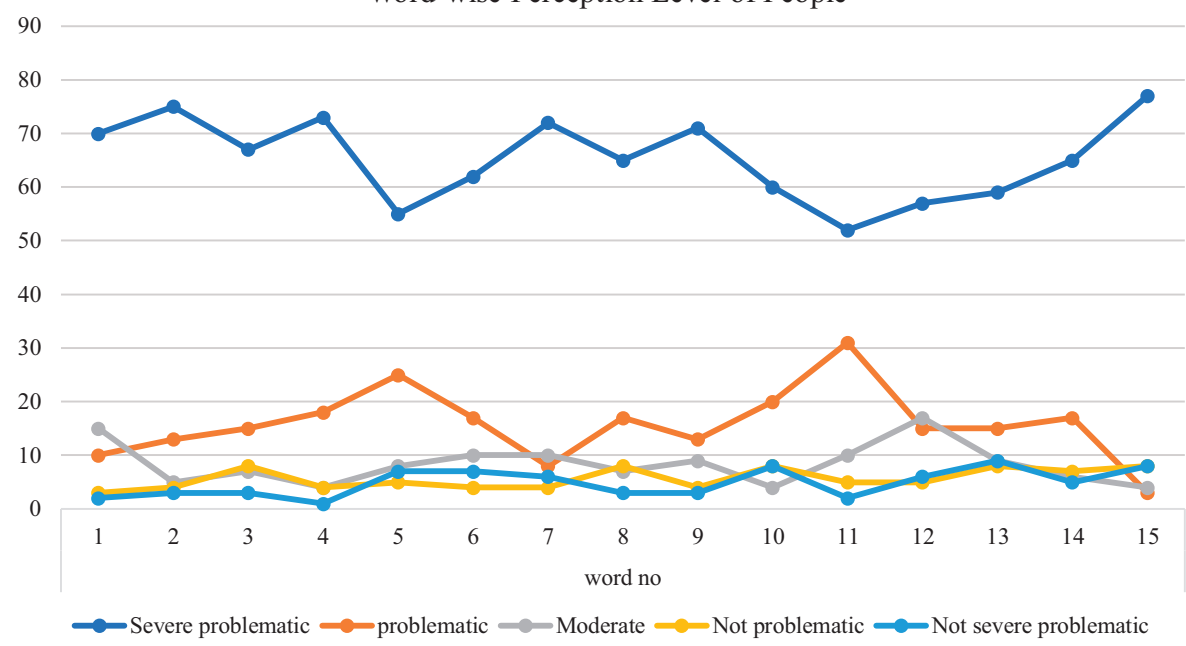

Source(s): Field Survey, 2020

With a dependent variable perception level of the consumers, the multiple regression results show (Table 5) the $\beta$ and $p$ (Sig. level) values for five imperial independent variables (Solid waste disposal into the drainage, absence of operation and maintenance system, small discharge capacity with blocked in the current drains, nonappearance of combined drainage network of roadside drains and unplanned drainage system) are $\beta=0.002, p=0.000$;
Figure 6.

Word-wise perception level on waterlogging problem 
EFCC

2,3

122

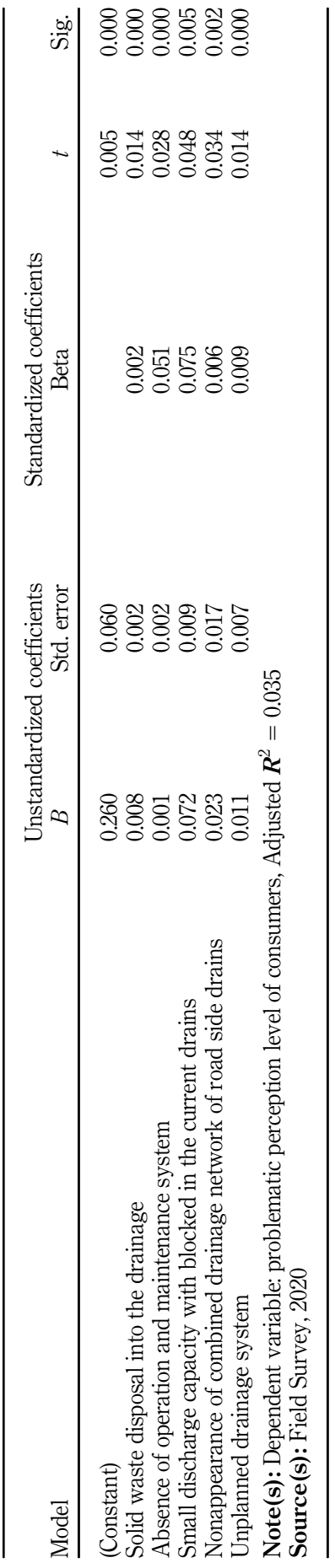

Table 5.

Regression model of problematic perception level of consumers 
$\beta=0.051, p=0.000 ; \beta=0.075, p=0.000 ; \beta=0.006, p=0.002$ and $\beta=0.014, p=0.000$, respectively.

The regression outcome shows that (Solid waste disposal into the drainage, absence of operation and maintenance system, small discharge capacity with blocked in the current drains, nonappearance of combined drainage network of roadside drains and unplanned drainage system) have a significant influence on the level of problematic perception level of consumers. The complete regression model was statistically significant with the $F$ $(3,93)=15.99, p<0.001$ and adjusted $R^{2}=0.035$.

The Pearson connection coefficient, moreover called the item second relationship coefficient, is spoken to by $r . \rho$ is the general population from which the example was drawn. The coefficient is estimated on a scale from -1 through 0 to +1 . If the connection coefficient is worth becomes positive, an excellent relationship may exist among the factors (Sedgwick, 2012) (see Table 6).

Table 5 shows the causes of waterlogging via a correlation matrix with the level of significance, the following table shows (Table 5) the degree of correlation with adjusted $R^{2}=0.030$.

The step of correlation, yet, varies between the variables with the solid waste disposal into the drainage having the upmost correlation of 1 trailed by absence of operation and maintenance system (0.175), small discharge capacity with blocked in the current drains $(0.117)$, nonappearance of combined drainage network of roadside drains $(-0.033)$ and unplanned drainage system $(-0.101)$. From these outcomes, the study discovers that the solid waste disposal into the drainage and the small discharge capacity with blocked in the current drains positively correlate with each

\begin{tabular}{|c|c|c|c|c|c|c|}
\hline & & $\begin{array}{l}\text { Solid } \\
\text { waste } \\
\text { disposal } \\
\text { into the } \\
\text { drainage }\end{array}$ & $\begin{array}{l}\text { Absence of } \\
\text { operation } \\
\text { and } \\
\text { maintenance } \\
\text { system }\end{array}$ & $\begin{array}{l}\text { Small } \\
\text { discharge } \\
\text { capacity } \\
\text { with } \\
\text { blocked in } \\
\text { the } \\
\text { current } \\
\text { drains }\end{array}$ & $\begin{array}{l}\text { Nonappearance } \\
\text { of combined } \\
\text { drainage } \\
\text { network of road } \\
\text { side drains }\end{array}$ & $\begin{array}{c}\text { Unplanned } \\
\text { drainage } \\
\text { system }\end{array}$ \\
\hline \multirow{2}{*}{$\begin{array}{l}\text { Solid waste } \\
\text { disposal into the } \\
\text { drainage }\end{array}$} & $\begin{array}{l}\text { Pearson } \\
\text { correlation }\end{array}$ & 1 & 0.175 & $0.117 * *$ & -0.033 & -0.101 \\
\hline & $\begin{array}{l}\text { Sig. (two- } \\
\text { tailed) }\end{array}$ & & 0.115 & 0.003 & 0.718 & 0.285 \\
\hline \multirow{2}{*}{$\begin{array}{l}\text { Absence of } \\
\text { operation and } \\
\text { maintenance } \\
\text { system }\end{array}$} & $\begin{array}{l}\text { Pearson } \\
\text { correlation }\end{array}$ & 0.175 & 1 & $0.183^{* *}$ & 0.063 & 0.106 \\
\hline & $\begin{array}{l}\text { Sig. (two- } \\
\text { tailed) }\end{array}$ & 0.115 & & 0.002 & 0.534 & 0.294 \\
\hline $\begin{array}{l}\text { Small discharge } \\
\text { capacity with }\end{array}$ & $\begin{array}{l}\text { Pearson } \\
\text { correlation }\end{array}$ & $0.117^{* *}$ & $0.183^{* *}$ & 1 & 0.102 & $0.082^{* *}$ \\
\hline $\begin{array}{l}\text { blocked in the } \\
\text { current drains }\end{array}$ & $\begin{array}{l}\text { Sig. (two- } \\
\text { tailed) }\end{array}$ & 0.003 & 0.002 & & 0.000 & 0.000 \\
\hline \multirow{4}{*}{$\begin{array}{l}\text { Nonappearance } \\
\text { of combined } \\
\text { drainage } \\
\text { network of road } \\
\text { side drains } \\
\text { Unplanned } \\
\text { drainage system }\end{array}$} & $\begin{array}{l}\text { Pearson } \\
\text { correlation }\end{array}$ & -0.033 & 0.063 & 0.058 & 1 & -0.040 \\
\hline & $\begin{array}{l}\text { Sig. (two- } \\
\text { tailed) }\end{array}$ & 0.718 & 0.534 & 0.102 & & 0.691 \\
\hline & $\begin{array}{l}\text { Pearson } \\
\text { correlation }\end{array}$ & -0.101 & 0.106 & $0.082^{* *}$ & -0.040 & 1 \\
\hline & $\begin{array}{l}\text { Sig. (two- } \\
\text { tailed) }\end{array}$ & 0.285 & 0.294 & 0.000 & 0.691 & \\
\hline
\end{tabular}

Note(s): **Correlation is significant at the 0.01 level (two-tailed). $\boldsymbol{R}^{2}=0.030$

The causes of waterlogging

123
Table 6. causes of waterlogging 
EFCC 2,3

124

other. This correlation value amongst the two variables is 0.117 , with a significant value of 0.003 . These values specify that the solid waste disposal into the drainage influences the small discharge capacity with blocked in the current drains.

Between small discharge capacity with blocked in the current drains and the absence of operation and maintenance system, the correlation value is 0.1830 .183 , and the significant value is 0.002 . That means that amongst these two variables, there is positive and significant value. This relationship between small discharge capacity with blocked in the current drains and absence of operation and maintenance system shows that absence of operation and maintenance system has a vital influence on small discharge capacity with blocked in the existing drains.

The unplanned drainage system has a harmonizing coloration with the small discharge capacity with blocked in the current drains having a positive value of 0.294 with a significant level of 0.000 . This result means that the unplanned drainage system affects small discharge capacity with blocked in the current drains.

\section{Conclusion}

The study's main aim was to find out the existing drainage condition and waterlogging situation and causes of waterlogging with people's perception. After analyzing the data, the study finds that locations that are identified by the consumers should include in the future drainage improvement plan. Also, this study finds five causes (Solid waste disposal into the drainage, absence of operation and maintenance system, small discharge capacity with blocked in the current drains, nonappearance of combined drainage network of roadside drains, unplanned drainage system) as the prime cause identified by the consumers. Moreover, the study finds the absence of operation and maintenance system, solid waste disposal into the drainage and unplanned drainage system as the influencing causes on small discharge capacity with blocked in the current drains.

To solve the waterlogging problem, these causes need to be considered for the future drainage improvement plan. The primary discharge of water in the Pabna Municipality is the Icamoti river. But the river is almost dead now. As a result, water cannot be discharged into the river during the monsoon season and causes waterlogging. The natural flow of the river should be ensured. Also, the drains of the municipality should be eviscerated regularly to avoid the obstruction of drains. Strong waste administration ought to be led appropriately so that water can stream effectively at their expected speed. The government should implement the previous drainage master plan properly, and a participatory approach should be taken for the plan. By all these measures, the waterlogging problem in Pabna Municipality can be solved.

\section{References}

ADB [Asian Development Bank] (2014), Bangladesh: Preparing the Third Urban Governance and Infrastructure Improvement (Sector) Project, Technical Assistance Consultant's Report, BBS, available at: https:/www.adb.org/projects/documents/preparing-third-urban-governance-andinfrastructure-improvement-sector-project-tacr.

Alam, M. and Rabbani, M.G. (2007), "Vulnerabilities and responses to climate change for Dhaka", Environment and Urbanization, Vol. 19 No. 1, pp. 81-97.

Anisha, N.F. and Hossain, S. (2014), "A case study on waterlogging problems in an urban area of Bangladesh and probable analytical solution", International Conference on Advance in Civil Engineering, Chittagong.

Atauzzaman, M., Rokib Uddin, M. and Ram Barman, N. (2019), "Drainage and water logging in Pabna municipality of Bangladesh: a case study", Journal of Civil, Construction and Environmental Engineering, Vol. 4 No. 6, p. 100, doi: 10.11648/j.jccee.20190406.12. 
Bansal, N., Mukherjee, M. and Gairola, A. (2015), "Causes and impact of urban flooding in Dehradun", International Journal of Current Research, Vol. 7 No. 2, pp. 12615-12627.

Blanc, J., Hall, J.W., Roche, N., Dawson, R.J., Cesses, Y., Burton, A. and Kilsby, C.G. (2012), "Enhanced efficiency of pluvial flood risk estimation in urban areas using spatial-temporal rainfall simulations", Journal of Flood Risk Management, Vol. 5 No. 2, pp. 143-152, doi: 10.1111/j.1753318x.2012.01135.x.

Cazenave, A., Dieng, H.B., Meyssignac, B., Von Schuckmann, K., Decharme, B. and Berthier, E. (2014), "The rate of sea-level rise", Nature Climate Change, Vol. 4 No. 5, p. 358.

Hasan, M.R., Hossain, T., Khan, L.A. and Afrin, S. (2018), "Seasonal water logging problem in an urban area of Bangladesh: a study on Pabna Pourashava", 1st National Conference on Water Resources Engineering (NCWRE 2018), Chittagong University of Engineering and Technology, Chittagong.

Huq, S. and Alam, M. (2003), Flood Management and Vulnerability of Dhaka City, Bangladesh Center of Advance Studies (BCAS), Dhaka.

Islam, M.K., Chowdhuary, S., Chisty, K.U. and Rahman, A. (2015), "Community participatory tools for water logging vulnerability assessment in Chittagong city corporation area", Journal of Bangladesh Institute of Planners, Vol. 8, pp. 221-131.

Knight, L. (2011), "World disasters report 2009”, available at: http:/www.redcross.se/wdr.

Kobra, K.M., Hossain, T., Sadat, M.N., Ali, S. and Nahid, H. (2018), "Role of NGOs for poverty alleviation in rural Bangladesh: a study on Ramnathpur village, Rangpur", doi: 10.13140/RG.2.2. 25271.78248

Majumder, A.K., Hossain, M.S. and Nayeem, A.A. (2018), “Assessment of people's perception on water logging in Chittagong city corporation area, Bangladesh", International Journal of Multidisciplinary Research and Development, Vol. 5 No. 2, pp. 104-107.

MIDP [Municipality Infrastructure Development Plan] (2008), Municipality Infrastructure Development Plan, MIDP, Pabna Municipality, Pabna.

Mowla, Q.A. and Islam, M.S. (2013), "Natural drainage system and water logging in Dhaka: measures to address the problems", Journal of Bangladesh Institute of Planners, Vol. 6, pp. 23-33.

Parvez, M. and Islam, S. (2020), "Sites suitability analysis of potential urban growth in Pabna municipality area in Bangladesh: AHP and geospatial approaches", Journal of Geographical Studies, Vol. 3 No. 2, pp. 82-92, doi: 10.21523/gcj5.19030204.

Sajikumar, N. and Remya, R.S. (2015), "Impact of land cover and land use change on runoff characteristics", Journal of Environmental Management, Vol. 161, pp. 460-468, doi: 10.1016/j. jenvman.2014.12.041.

Sato, T. (2006), Fundamental Characteristics of Flood Risk in Japan's Urban Areas, Society to Emerging Disaster Risks in Mega-Cities, Terra, pp. 23-40.

Sedgwick, P. (2012), "Pearson's correlation coefficient”, BMJ, Vol. 345, doi: 10.1136/bmj.e4483.

Sultana, N. (2012), "Assessment of water availability, drainage and irrigation problems in some selected locations of Pabna district", Unpublished thesis, Department of Civil Engineering, Bangladesh University of Engineering and Technology, Dhaka, pp. 15-20.

Tam, V.T. and Nga, T.T.V. (2018), "Assessment of urbanization impact on groundwater resources in Hanoi, Vietnam", Journal of Environmental Management, Vol. 227, pp. 107-116, doi: 10.1016/j. jenvman.

Tang, X., Shu, Y., Lian, Y., Zhao, Y. and Fu, Y. (2018), "A spatial assessment of urban waterlogging risk based on a Weighted Naïve Bayes classifier", Science of the Total Environment, Vol. 630, pp. 264-274, doi: 10.1016/j.scitotenv.2018.02.172.

Tawhid, K.G. (2004), "Causes and effects of water logging in Dhaka City, Bangladesh”, TRITA-LWR unpublished master thesis, Royal Institute of Technology, Stockholm.
The causes of waterlogging 
EFCC 2,3

Tran, D., Xu, D., Dang, V. and Alwah, A.A.Q. (2020), "Predicting urban waterlogging risks by regression models and internet open-data sources", Water, Vol. 12 No. 3, p. 879, doi: 10.3390/ w12030879.

\section{Further reading}

Akter, A., Mohit, S.A. and Chowdhury, M.A.H. (2017), "Predicting urban storm water-logging for Chittagong city in Bangladesh", International Journal of Sustainable Built Environment, Vol. 6 No. 1, pp. 238-249, doi: 10.1016/j.jjsbe.2017.01.005.

Ashraf, M.A. (2012), "Waterlogging stress in plants: a review", African Journal of Agricultural Research, Vol. 7 No. 13, doi: 10.5897/ajarx11.084.

Ashraf, M.A. and Chowdhury, M.S.A. (1970), "Drainage planning in the cities of Bangladesh: case study of drainage and water logging in Chaktai Commercial Area, Chittagong", Journal of Bangladesh Institute of Planners, Vol. 2, pp. 49-60, doi: 10.3329/jbip.v2i0.9556.

Awal, M.A. (2014), "Water logging in southwestern coastal region of Bangladesh: local adaptation and policy options", International Journal of Scientific Innovation, Vol. 4 No. 1, pp. 145-159.

Patel, A. (2020), "Stormwater analysis and solution of waterlogging in Kothrud region, Pune", International Journal for Research in Applied Science and Engineering Technology, Vol. 8 No. 6, pp. 1340-1348, doi: 10.22214/ijraset.2020.6216.

Sarkar, S.K., Rahman, M.A., Esraz-Ul-Zannat, M. and Islam, M.F. (2020), "Simulation-based modeling of urban waterlogging in Khulna city", Journal of Water and Climate Change. doi: 10.2166/wcc. 2020.256 .

Subrina, S. and Chowdhury, F.K. (2018), "Urban dynamics: an undervalued issue for water logging disaster risk management in case of Dhaka city, Bangladesh”, Procedia Engineering, Vol. 212, pp. 801-808, doi: 10.1016/j.proeng.2018.01.103.

\section{Corresponding author}

Mazed Parvez can be contacted at: parvezpust30@gmail.com

For instructions on how to order reprints of this article, please visit our website:

www.emeraldgrouppublishing.com/licensing/reprints.htm

Or contact us for further details: permissions@emeraldinsight.com 